\title{
NORMA KESUSILAAN SEBAGAI BATASAN PORNOGRAFI MENURUT UNDANG-UNDANG NO. 44 TAHUN 2008
}

\author{
Hwian Christianto ${ }^{1}$
}

\begin{abstract}
The launching of UU. No.44 Tahun 2008 about pornography in one side is providing a standard of law for a pornography-taking measures comprehensively. But in another side, this pornography law actually does not formulate clearly and firmly about how they will decide if it is categorized as pornography or not. In verse 1 of 1 UU. No. 44 Tahun 2008, just provides a labeling some materials of moral act-breaking, categorized as pornography criminal act. The interpretation about what and how the moral norm considered as, can play its role as an examiner of pornography's judgment. In order to handle it, a judge and a lawyer need to know what is the moral norm about, and how it is considered as a law historically or normatively.
\end{abstract}

Kata kunci: norma, pornografi, hukum

\section{Pendahuluan}

Terhitung tanggal 26 November 2008 Indonesia telah memiliki satu undang-undang baru yang mengatur masalah kesusilaan, undang-undang ini disebut Undang-undang Pornografi. Dengan mengingat perkembangan jaman yang semakin hari semakin canggih ternyata membawa pengaruh negatif bagi kepribadian bangsa. Kemudahan akses informasi baik melalui media elektronik maupun media komunikasi seakan menjadi 'ruang bebas' bagi masyarakat untuk menikmati informasi atau tampilan yang pada dasarnya melanggar kesusilaan. Sebagai contoh, kasus pemasangan gambar porno baik di media cetak ataupun internet sangat merebak. Keberadaan UU Pornografi ini juga mendapatkan apresiasi negatif bagi sebagian masyarakat karena dianggap mengekang kebebasan berekspresi yang pada hakekatnya merupakan hak asasi manusia dan tidak menghargai kebudayaan bangsa Indonesia sendiri. Kebudayaan Indonesia yang dimaksud disini berupa tata berpakaian, tata upacara atau beberapa kebiasaan yang dapat dinilai sebagai perbuatan pornografi berdasarkan UU Pornografi.

1 Penulis adalah mahasiswa Program Magister Ilmu Hukum Pasca Sarjana Universitas Airlangga Surabaya tahun 2007 Alamat korespondensi: hwall4jc@yahoo.co.id. 
Pemahaman tentang konsep hukum pornografi di dalam hal ini memainkan peranan yang sangat penting karena di dalamnya akan diperoleh satu pengertian yang mendalam terhadap rumusan perbuatan pidana pornografi, ruang lingkup dan batasannya sehingga dapat dihindari kesalah pahaman dalam menerapkan ketentuan hukum pornografi. Hanya saja jika diperhatikan dari sejak proses pembentukan, pembahasan hingga rancangan undang-undang (RUU) pornografi ini ternyata diwarnai berbagai pendapat pro dan kontra pertentangan dari kedua kelompok ini sebenarnya bermuara dari pemahaman akan nilai atau standar yang digunakan untuk menentukan suatu tindakan atau obyek itu sebagai perbuatan pornografi. Mengingat bangsa Indonesia sendiri terdiri dari masyarakat yang heterogen membawa satu implikasi logis adanya pemahaman akan suatu ukuran itu baik atau tidak (jika dalam pemahaman pornografi, perbuatan itu melanggar ukuran atau tidak ) sangat berbeda antara satu masyarakat dengan masyarakat yang lainnya. Terdapat banyak faktor yang mempengaruhi pertimbangan ukuran baik atau buruk ini, bisa dari sisi budaya suatu masyarakat, kebiasaan atau pun aturan setempat yang disepakati. Dengan demikian muncullah suatu ukuran nilai-nilai yang sangat bervariatif terhadap suatu perbuatan itu apakah melanggar pornografi.

Boleh dikatakan pembentukan Undang-undang Pornografi ini merupakan suatu tindakan yang sangat berani dari legislatif. Dengan menetapkan suatu aturan hukum yang mengatur Pornorafi dalam tingkat nasional (dalam bentuk undang-undang) berarti terdapat satu usaha menyatukan satu ukuran yang baku teerhadap suatu perbuatan atau obyek itu melanggar pornografi. Di dalam pasal 1 angka 1 UU No. 44 Tahun 2008, suatu perbuatan atau obyek dapat dipandang sebagai suatu perbuatan pornografi jika melanggar satu ukuran standar, norma kesusilaan. Norma kesusilaan ini ternyata menjadi batu uji bagi perbuatan atau segala bentuk obyek yang dianggap memiliki unsur pornografi. Hanya saja permasalahannya, UU No. 44 Tahun 2008 tidak menjelaskan dengan jelas dan tegas apakah yang disebut norma kesusilaan itu sendiri dan bagaimana menentukan ada atau tidaknya perbuatan pornografi terkait dengan penerapan norma kesusilaan itu sendiri. Hal ini jelas menimbulkan suatu pertanyaan besar tentang apa dan bagaimanakah norma kesusilaan itu? Bagaimanakah keberlakuannya sebagai ukuran untuk menilai ada atau tidaknya perbuatan atau obyek pornografi? Pemahaman akan norma kesusilaan ini begitu penting dan mendesak bagi siapa pun juga mengingat akhir-akhir ini suatu batasan perbuatan itu melanggar norma kesusilaan atau tidak bagi satu orang dengan orang lain ternyata tidak sama. Pembahasan akan norma kesusilaan ini harus dilakukan secara komprehensif melalui pendekatan filosofis-teoritis dengan tidak melupakan sisi histories yaitu 
konteks dimana masyarakat itu berada. Pemahaman akan norma kesusilaan secara tepat akan memberikan satu dasar legalitas yang pasti tentang sejauh mana norma kesusilaan itu mengatur.

Dari latar belakang diatas maka dapat diajukan beberapa permsalahan hukum, yaitu:

1. Apakah arti penting perlindungan norma kesusilaan di dalam ketentuan Hukum pidana?

2. Parameter apakah yang dapat digunakan untuk menentukan satu perbuatan sebagai pornografi?

\section{Kedudukan Nilai, Norma dan Aturan Hukum}

Masyarakat sebagai suatu kumpulan orang yang mengikatkan dirinya bersama dengan orang lain pada dasarnya menyepakati satu aturan yang mengatur hubungan atau transaksi yang sifatnya mengikat mereka satu sama lain demi tercapainya satu tujuan bersama. Pemahaman tentang aturan ini sering dipahami sebagai hukum (law) dalam pengertian yang luas. Seperti diungkapkan oleh Roscoe Pound. ${ }^{2}$ pemahaman tentang hukum itu sendiri harus dapat dibedakan antara hukum sebagai seperangkat nilai-nilai yang mengikat masyarakat dalam bentuk yang tertulis maupun tidak tertulis yaitu hukum sebagai ius. Dan dalam pengertian kedua, hukum sebagai seperangkat aturan hukum yang secara tertulis dan spesifik di teapkan oleh penguasa dalam suatu bentuk hukum (Undang-undang misalnya) disertai sanksi yang tegas, yaitu hukum sebagai lex. Dua pemahaman ini pada dasarnya sangat terkait satu dengan lainnya ketika pemahaman akan hukum ini di kaji secara lebih mendalam.

Keberadaan manusia sebagai individu pada hakekatnya memiliki nilainilai yang di terapkan pada dirinya ketika menghidupi kehidupannya. Pertemuan antara berbagai individu yang membawa konsep dan nilai yang berbeda-beda ini pada akhirnya dikristalisasi dalam sebuah nilai yang sifatnya komunal dalam suatu kumpulan individu yang di sebut masyarakat. Nilai merupakan suatu ukuran yang mutlak dan sifatnya tetap ketika melihat satu dan beberapa hal. Sebagai contoh, nilai kejujuran berlaku dalam suatu pemahaman akan pentingnya berkata-kata sesuai keadaan yang sebenarnya ketika melakukan segala transaksi. Soedarto menjelaskan hakekat nilai ini sebagai "ukuran yang disadari atau tidak disadari oleh suatu masyarakat

${ }^{2}$ Roscoe Pound, "Law Finding through Experience and Reason: Three Lestures", (Athens: University of Georgia Press, 1960), hal. 1. 
atau golongan untuk menetapkan apa yang benar, yang baik, dan sebagainya". ${ }^{3}$ Dapat dikatakan dalam sebuah kalimat, hakekat nilai itu sendiri merupakan "ukuran yang hidup" secara manunggal pada tiap manusia sebagai individu ketika berinteraksi atau pun tidak berinteraksi. Keberadaan nilai inilah yang sebenarnya menjadi suatu dasar bagi seseorang untuk berperilaku dan mengukur perilakunya sebagai sesuatu yang baik atau tidak.

Keberadaan nilai yang begitu menentukan sikap atau perilaku seseorang ini bersifat abstrak dikarenakan wujud dan bentuk dari nilai itu sendiri sudah merupakan anugerah dari Tuhan yang maha kuasa. Namun demikian, meskipun bersifat abstrak tidak berarti keberadaan nilai ini tidak dapat dipahami secara jelas atau tidak menentu. Justru sebaliknya keberadaan nilai menciptakan satu tatanan yang baik dan teratur ketika seseorang menyadari pentingnya keteraturan dan sesuatu yang baik itu dilakukan.

Permasalahan timbul manakala fakta di lapangan menunjukkan suatu sistim nilai (value system) dari suatu bangsa, masyarakat atau golongan ternyata tidak sama. ${ }^{4}$ Sebagai contoh, suatu ukuran nilai kehormatan bagi suatu golongan masyarakat tertentu begitu di agungkan dan menjadi prioritas sehingga bila ada seseorang yang menghina orang lain, kepada orang yang menghina itu harus diambil nyawanya. Jadi disini nilai kehormatan itu sama dengan nyawa seseorang. Berbeda halnya pada golongan atau bangsa lain yang memberikan respons berbeda ketika terjadi penghinaan atas orang lain. Terhadap orang yang melanggar ini hanya dikenakan sanksi berupa pembalasan atau denda maksimal penjara. Memang dari kenyataankenyataan ini dapat dilihat bahwa setiap masyarakat, golongan dan bangsa mempunyai system nilai yang berbeda tetapi perbedaan ini bukan pada esensinya. Bagi semua bangsa, kehormatan merupakan sebuah nilai yang harus di junjung tinggi karena menyangkut martabat. Ini berarti meskipun terdapat berbagai perbedaan dalam menyikapi suatu nilai, pada hakekatnya pemahaman akan arti penting suatu nilai tetap diakui sebagai sesuatu yang penting.

Pada perwujudan selanjutnya, nilai ini sendiri terurai dalam pelaksanaannya di dalam beberapa ketentuan-ketentuan yang sifatnya lebih konkrit. Dalam tahap perwujudan ini terbentuklah apa yang dinamakan dengan norma. Soedarto menjelaskan norma ini sebagai anggapan-anggapan yang sedikit atau banyak mengikat perbuatan seseorang dalam masyarakat. Menurutnya anggapan-anggapan ini berfungsi sebagai petunjuk bagaimana seseorang harus berbuat atau tidak harus berbuat. Jadi secara definitif

\footnotetext{
${ }^{3}$ Soedarto, "Hukum dan Hukum Pidana", (Bandung: Alumni, 1986), hal. 19.
}

${ }^{4}$ Ibid, hal. 20 . 
Soedarto menjelaskan hal ini sebagai "anggapan bagaimana seseorang harus berbuat atau tidak harus berbuat". 5 Dapat dikatakan satu hal yang membedakan antara 'norma' dengan 'nilai' terdapat pada bentuk yang lebih konkrit dan dapat diajukan rujukan yang tetap. Ini berarti arti penting dari norma ini di dalam pergaulan hidup manusia bagaikan sebuah kesepakatan bersama tentang 'aturan main' di dalam melakukan segala sesuatu termasuk baik atau buruknya sesuatu itu.

Hanya saja satu hal yang sangat menarik dari norma ini jika dibandingkan dengan bentuk nilai, pada norma ini memiliki sifat mendasar tentang apa yang seharusnya dilakukan sebagai sesuatu yang terbaik (ought) sangat berbeda dengan 'nilai' yang hanya memberi dasar apa yang baik. Perkembangan pengaturan selanjutnya menjadi lebih konkrit ketika apa yang seharusnya ini harus dituangkan dalam bentuk aturan hukum yang konkrit (tertulis). Hal ini mengingat ada begitu banyak interaksi dan bidang-bidang yang secara sektoral membutuhkan pengaturan secara spesifik. Pada titik inilah muncul produk-produk hukum berupa hukum tertulis seperti Undangundang atau peraturan perundang-undangan lainnya. Jadi pada bagian ini dapat dilihat satu korelasi yang erat antara hukum sebagai laws menjadi dasar bagi keberlakuan hukum dalam pengertian rule.

Permasalahan berikutnya pada masyarakat itu sendiri yang secara terus-menerus mengalami perkembangan dalam tiap jamannya. Dengan kata lain ukuran untuk menilai suatu perbuatan itu sebagai perbuatan yang asusila atau tidak benar-benar mengikuti perkembangan jaman. Topo Santoso dalam tulisannya mengutip pendapat Sahetapy dan Reksodiputro yang mengkaitkan pengaruh perkembangan masyarakat ini begitu beriringan dengan pemahaman akan nilai hukum dari suatu norma di masyarakat sebagai akibat akselerasi pembangunan. ${ }^{6}$ Hanya saja tidak berarti 'akselerasi' ini menyebabkan hapusnya nilai kesusilaan di dalam masyarakat. Nilai kesusilaan tetap di pahami sebagai bagian yang integral dari suatu manusia ketika bereksistensi dengan sesamanya. Dengan kata lain, pemahaman akan nilai kesusilaan ini memang terus akan berkembang, bukan di revisi tetapi akan dilengkapi dan semakin 'adaptable' dengan kondisi masyarakat tanpa harus menghilangkan ciri khas (tatanan) suatu masyarakat.

${ }^{5}$ Ibid, hal. 19.

"Topo Santoso, "Masalah Delik Perzinahan di Indonesia Dewasa Ini", Majalah Hukum \& Pembangunan, Tahun XXV, No.2 (April 1995), hal. 154-155. 


\title{
III. Nilai Kesusilaan sebagai Norma
}

Pada setiap masyarakat selalu terdapat pengakuan akan tatanan yang baik dan bermoral. Oleh karena terkait dengan masalah moral maka pemahaman akan nilai ini tidak akan terlepas dari seberapa jauh suatu masyarakat itu memahami apa yang baik dan tidak baik itu dalam ukuran waktu. Termasuk dalam hal ini pemahaman dan pengajaran akan pentingnya nilai-nilai susila yang baik bagi bangsa Indonesia sebenarnya sudah ada sejak dahulu kala seperti tampak dengan adanya delik-delik adapt di bidang kesusilaan. Seperti bekekaruh misalnya, merupakan satu bentuk delik adat susila yang melarang perbuatan zina seorang yang telah terikat dalam perkawinan dengan orang lain yang bukan pasangannya. ${ }^{7}$ Perbuatan ini disebut sebagai perbuatan asusila setelah di saksikan oleh Kramadesa setempat yang menyatakan adanya pelanggaran atas tatanan hidup masyarakat sehingga kepada si pelanggar harus dikenakan sanksi untuk mengembalikan kerukunan masyarakat itu.

Masuknya agama Hindu juga memberikan satu pengaruh yang berarti bagi pemahaman apa itu nilai susila. Hal ini dapat dilihat dari terbentuknya hukum adat yang mendasarkan dirinya pada kepercayaan Hindu untuk mencapai Moksartam Jagadhita yaca iti Dharma (bahwa agama Hindu Dharma bertujuan untuk mencapai moksa (moksartam) dan mencapai kesejahteraan hidup (Yagathirta). Dalam kaitanya dengan delik susila, di dalam lontar Padma Bhumi di atur tentang

\begin{abstract}
Bila ada orang yang bercinta-cintaan dalam lingkungan pura (berbuat mesum) dan ada orang lain yang mengetahui pada waktu kejadian itu tetap tidak memberitahukan pada kelihan pura kemudian terbukti orang itu berbuat mesum maka didenda sebesar 5700 kepeng dan memperbaiki serta menyucikan pura itu sepatutnya, karena pura dikotorkan (leteh). Orang yang mengetahui perbuatan itu juga dikenakan denda sebesar 4500 kepeng karena kesalahannya tidak melaporkan kejadian itu kepada kelihan pura. ${ }^{8}$
\end{abstract}

${ }^{7}$ Hermien Hadiati Koeswadji, "Aspek Budaya dalam Pemidanaan Delik Adat", dalam BPHN, Simposium Pengaruh Kebudayaan/agama terhadap Hukum Pidana, (Bandung: Bina Cipta, 1975), hal. 48-49.

${ }^{8}$ Tjokorda Raka Dherana \& P. Made Widnyana, "Agama Hindhu dan Hukum Pidana Nasional", dalam BPHN, Ibid., hal. 113. 
Sekilas nampak di dalam aturan di atas perbuatan asusila ini semula merupakan urusan pribadi dari seseorang tetapi menjadi urusan masyarakat luas ketika terjadi pelanggaran yang dinilai tidak pantas dan membahayakan moksa dan yagathirta. Sehingga terhadapnya harus dillakukan pemulihan dengan memberikan sanksi kepada pelanggarnya sebagai bentuk pertanggung jawaban secara pribadi pada masyarakat sekaligus tatanan alam. Kitab Sarasmuscaya juga memberikan larangan perbuatan asusila seperti dalam Sloka 413, 422 dan 423. ${ }^{9}$ Dengan menekankan pada pentingnya keseimbangan magis yang harus di jaga di dalam masyarakat, Atmadja menjelaskan berlakunya "azas patut"10 sebagai dasar bagi terwujudnya tatanan yang ideal bagi masyarakat hindu, khususnya ketika terjadi perkara.

Perkembangan selanjutnya agama Islam mengajarkan satu pemahaman akan pentingnya menjaga moralitas di dalam nilai susila ini sebagai suatu jati diri dari bangsa. Tampak dalam Kitab Suci Al-Qur'an dan Sunnah Nabi Muhammad telah di jelaskan secara pasti hukuman-hukuman dari berbagai kejahatan, mengingat di dalam agama Islam kejahatan itu berakar dalam jiwa si penjahat dan juga bahayanya sangat besar bagi masyarakat. ${ }^{11}$ Abdulgani Karim lebih lanjut menegaskan satu kelompok delik susila dengan menyebut kejahatan "Hukuman terhadap pelanggaran kehormatan dengan zina dan tuduhan berzina, ini di sebutkan oleh Allah dalam Surat IV ayat 15 dan 16 dan dalam Surat An-Nur ayat 2 dan 3". ${ }^{2}$ Mengenai larangan terhadap perbuatan asusila sendiri tampak dalam beberapa ayat lain seperti: Surat AnNur ayat 31, surat Al Ahzab ayat 59, dan Surat Al-Isro' ayat 32.

Norma-norma agama Islam ini menjadi hal yang sangat penting mengingat norma-norma ini lahir dengan berdasarkan pada ajaran agama Islam sendiri.

Di dalam pemahaman ini peran kekristenan pun ikut mewarnai penghayatan akan nilai-nilai susila. Di dalam Alkitab di cantumkan dengan tegas larangan zinah sebagai salah satu perbuatan asusila, seperti dalam Amsal 6:32, Injil Matius 5:27, Markus 22:23, Surat I Timotius 1:10 dan I

${ }^{9}$ Ismu Gunadi Widodo, "Aspek Yuridis Pornorafi/Aksi: Memahami Wewenang Diskresi dalam Penyidikan Tindak Pidana Pornografi/Aksi”, (Surabaya: Airlangga University Press, 2006), hal. 81-82.

${ }^{10}$ Atmadja, "Asas Patut sebagai Asas Kerja Penyelesaian Perkara menurut Hukum Adat Bali", Majalah Hukum \& Pembangunan, Tahun XI, No. 1 (Januari 1981), hal. 53-55.

${ }^{11}$ Abdulgani Karim, "Pengaruh Agama Islam terhadap Hukum Pidana Nasional", dalam BPHN, Ibid., hal. 62.

${ }^{12}$ Ibid. 
Tesalonika 4:3. Sedangkan secara normatif tampak dalam pemberlakuan Wetboek van Strafrecht untuk negeri Belanda tahun 1915 yang merupakan duplikat dari Wetboek van Strafrecht Balenda tahun 1881. Kemudian setelah kemerdekaan beberapa ketentuan hukum pidana ini di cabut berdasarkan UU RI No. 1 (Berita RI tahun II No. 5 tanggal 15 MAret 1946) dan UU RI 1946 - 20 tentang pidana tutupan (Berita RI No. 24 tahun ke II tanggal 1 dan 15 Nopember 1946) karena di anggap tidak sesuai dengan kepribadian dan tujuan bangsa Indonesia. Pengaturan delik susila dalam KUHP pada hakekatnya dilarang oleh agama Kristen. Baik itu 'cabul' atau 'pornografi' masalah perumusan ini di tinjau dari segi agama ialah masalah kesusilaan (aanstootelijk voor de eerbaarheid). Wirjono menjelaskan hal ini dengan "kesusilaan yang dirusak ini sebenarnya apa yang dirasakan sebagai kesusilaan oleh segenap orang biasa dalam suatu masyarakat tertentu. Maka dapat dikatakan, bahwa kini tersinggung rasa susila kita". ${ }^{13} \mathrm{Di}$ sinilah keberlakuan norma agama dari setiap ajaran itu begitu membawa pengaruh dan berinteraksi dengan norma adat yang ada sebelumnya membentuk suatu norma ksusilaan yang baku.

Dari penjelasan historis di atas dapat dilihat dengan jelas bahwa ketika masyarakat ada hukum pun sudah ada. Hal ini tepat seperti adagium yang mengatakan "ubi societas ubi ius" yang lebih menekankan hubungan yang erat dan saling menjamin antara hukum dan masyarakat itu sendiri. Bagi bangsa Indonesia, pemahaman akan nilai susila ini sudah bermur ratusan tahun dan bahkan sudah dapat dikatakan menjadi satu bagian yang merupakan kepribadian bangsa Indonesia yang sepanjang waktu terus mengalami perkembangan. Dalam hal inilah perwujudan nilai susila di lakukan secara lebih serius dalam bentuk norma susila yang berlaku di tiap golongan masyarakat, baik berbagai suku dan bangsa tetapi memliki satu pengakuan yang sama tentang pentingnya perlindungan dan di jaganya nilai kesusilaan sebagai identitas bangsa Indonesia.

\section{Kedudukan Norma Kesusilaan di dalam Hukum Pidana}

Keberadaan norma kesusilaan dalam hukum pidana dapat dipahami melalui 2 sisi kedudukan, yaitu norma kesusilaan sebagai dasar keberlakuan Ketentuan hukum dan norma kesusilaan sebagai norma yang bersifat publik.

${ }^{13}$ Wirjono Prodjodikoro, "Tindak-tindak Pidana tertentu di Indonesia", (Bandung: 
1. Norma Kesusilaan sebagai Dasar dari Keberlakuan Ketentuan Hukum Pidana

Hubungan norma dengan ketentuan hukum seperti di pahami dalam teori hukum pada umumnya, memandang norma itu sebagai suatu sistim nilai yang mendasari keberlakuan ketentuan hukum itu. Dapat dikatakan eksistensi dari ketentuan hukum itu sangat bergantung dari seberapa jauh dan banyak norma yang dimuat. Sebagai contoh, apabila terdapat norma kesusilaan yang mengatur "seorang gadis harus berpakaian sopan" maka ketentuan hukum yang mengatur pun harus menjabarkan lebih konkrit dengan mengatur "setiap wanita harus mengenakan busana yang tidak minim". Dari contoh ini dapat dilihat bahwa antara norma dan ketentuan hukum ini terdapat kaitan yang begitu erat sehingga merupakan satu keharusan bagi sebuah ketentuan hukum untuk menentukan norma apa yang menjadi rujukannya. Peter Mahmud menjelaskan hakekat norma hukum dari segi tujuannya untuk mengatur manusia sebagai makhluk sosial dan aspek lahiriah manusia ${ }^{14}$ sehingga keberadaan norma kesusilaan ini menjadi dasar bagi pemberlakuan norma hukum.

Norma di dalam hukum pidana sebenarnya lebih di kenal dengan "prinsip" atau "asas" yang tempatnya begitu mendasar dan masih bersifat abstrak sehingga membutuhkan langkah konkrit untuk melaksanakannya. Tindakan pelaksanaan asas inilah yang di sebut dengan pembentukan ketentuan hukum dalam sebuah peraturan undang-undang. Pemahaman ini berangkat dari satu pernyataan bahwa norma hukum itu berkedudukan sebagai Meta Kaidah. ${ }^{15}$ Sebagai meta norma, norma hukum berkedudukan sebagai norma perilaku yang mendasarkan dirinya pada norma atau kaidah penilaian (waardenings-normen). Di dalam pemahaman hukum pidana, ketentuan hukum kesusilaan ini sebenarnya dapat di tarik lebih mendasar pada norma yang mendasari pembentukannya yaitu norma kesusilaan. Kedudukan ini harus dapat dibedakan secara jelas mengigat keberadaan hukum sangat berbeda jauh dengan normanorma lainnya.

2. Norma Kesusilaan sebagai Norma yang bersifat Publik

${ }^{14}$ Peter Mahmud Marzuki, "Pengantar Ilmu Hukum", (Jakarta: Kencana Prenda Media, 2008), hal. 86.

15 J.J.H. Bruggink, "Refleksi tentang Hukum", alih bahasa: Arief Sidharta, (Bandung: Citra Aditya Bakti, 1999), hal. 103-104. 
Aspek publik disini haruslah dipahami sebagai faktor kepentingan umum yang menjadi dasar bagi pemberlakuan suatu norma atau ketentuan hukum di masyarakat. Terkait dengan hal ini, norma kesusilaan ternyata mengerjakan fungsi yang sangat penting. Norma kesusilaan merupakan norma yang memberikan dasar atau ukuran bagi suatu perbuatan yang baik (bermoral) atau tidak. Jika dikaitkan dengan norma lain seperti norma agama, norma sopan santun dan norma hukum maka norma kesusilaan lebih memberikan dasar penilaian (ukuran) yang berlaku bagi pribadi seseorang. Sudikno menjelaskan hakekat norma kesusilaan ini dengan "kaedah kesusilaan berhubungan dengan manusia sebagai individu karena menyangkut kehidupan pribadi manusia. Asal atau sumber kaedah kesusilaan adalah dari manusia sendiri, jadi bersifat otonom dan tidak ditujukan kepada sikap lahir tetapi di tujukan kepada sikap batin manusia juga". ${ }^{16}$ Hakekat norma kesusilaan menurut Sudikno lebih merupakan masalah pribadi individu ketika melihat suatu perbuatan itu jahat misalnya penipuan, pencurian atau pemerkosaan apakah dirinya merasa menyesal, malu, takut atau rasa bersalah.

Pada pemahaman ini, norma kesusilaan lebih diposisikan sebagai suatu standar bagi individu dalam berespons terhadap suatu perbuatan apakah baik atau tidak. Sedangkan terhadap norma yang lainnya, norma kesusilaan ini bersama-sama dengan norma agama menjadi dasar bagi keberlakuan norma sopan santun dan norma hukum. Jadi norma agama dan norma kesusilaan itu sebagai dasar untuk memahami adanya nilai dan ukuran yang mendasar sedangkan norma sopan santun dan norma hukum lebih pada pengaturan yang bersifat umum.

Dalam hubungannya sebagai norma yang bersifat publik sebenarnya norma kesusilaan ini sendiri memberikan dasar keberlakuan yang sifatnya luas. Sifat luas ini sendiri sebenarnya di dasarkan atas pertimbangan bahwa tiap individu memiliki satu dasar penilaian yang sama bahwa sesuatu itu salah atau buruk sehingga sifatnya universal atau umum. Adami Chazawi menggunakan istilah yang berbeda tentang perbuatan asusila ini dengan "tindak pidana kesopanan" namun pada intinya dimaknai sama sebagai upaya untuk "melindungi kepentingan hukum (rechtsbelang) dari rasa kesopanan masyarakat (rasa kesusilaan termasuk di dalamnya)". 17 Sebagai

\footnotetext{
${ }^{16}$ Sudikno Mertokusumo, "Mengenal Hukum”, (Yogyakarta: Liberty, 1999), hal. 7.
} 
contoh, "mempertontonkan orang telanjang" merupakan suatu perbuatan yang di cela atau di anggap buruk oleh semua golongan masyarakat. Di dalam praktek yang dijumpai perbedaan perlakuan itu bukan mengisyaratkan adanya sikap yang berbeda dimana satu masyarakat itu melarang dan masyarakat yang lain itu memperbolehkan. Tiap masyakarat itu pasti melarang dan menganggap perbuatan itu sebagai perbuatan yang tidak baik, hanya saja respons terhadap perbuatan ini yang berbeda dari tiap masyarakat.

Sifat publik dari norma kesusilaan ini terdapat dalam esensi dari norma kesusilaan ini sendiri di dalam menjaga standar atau ukuran moralitas dari suatu masyarakat. Sungguh pun norma kesusilaan ini bersumber pada hati nurani manusia secara individu pengakuan. keberadaan dan pelaksanaannya sangat esensial karena menyangkut hakekat manusia itu sendiri sebagai manusia yang beradab. Berbahayanya suatu perbuatan yang asusila bisa berdampak negatif pada moral dan penghayatan nilai harkat dan martabat manusia. Bagi bangsa Indonesia sendiri, penghayatan norma kesusilaan ini lebih dari sekedar urusan pribadi individu tetapi menyangkut urusan kepribadian suatu bangsa. Hal ini memang bersesuaian dengan sifat Hukum pidana itu sendiri.

Hukum pidana adalah hukum (tentang penjatuhan) sanksi: ihwal penegakan norma-norma (aturanaturan) oleh alat-alat kekuasaan (negara) yang ditujukan untuk melawan dan memberantas perilaku yang mengancam keberlakuan norma tersebut. ${ }^{18}$

Sifat publik dari norma kesusilaan dengan hukum pidana dapat saling terkait dalam hal ini.

Permasalahannya sekarang jika norma kesusilaan itu memang bersumber dari hati nurani manusia secara individu, perlukah norma ini di atur dalam sebuah ketentuan hukum secara tertulis (di dalam UU misalnya). Bukankah norma kesusilaan ini merupakan masalah nurani yang sifatnya lebih subyektif. Untuk menjawab pertanyaan ini 2005), hal. 1.

17 Adami Chazawi, "Tindak Pidana mengenai Kesopanan", (Jakarta: Rajawali Pers,

${ }^{18}$ Jan Remmelink, "Hukum Pidana: Komentar atas Pasal-pasal Terpenting dari Kitab Undang-undang Hukum Pidana Belanda dan Padanannya dalam Kitab Undang-undang Hukum Pidana Indonesia”, (Jakarta: Gramedia Pustaka Utama, 2003), hal. 6. 
perlu di pahami hakekat norma kesusilaan itu sendiri dalam kaitannya dengan norma hukum dan ketentuan hukum. Norma kesusilaan memang merupakan suatu ukuran yang berlaku secara individu tetapi ketika tiap individu ini membentuk satu ketertikatan dalam lembaga masyarakat, norma kesusilaan ini mulai bereaksi dengan norma-norma yang lain (agama, hukum dan adat) untuk berlaku. Tindakan pengaturan norma kesusilaan menjadi ketentuan hukum tertulis sebenarnya menaikkan tingkat keberlakuan norma kesusilaan itu menjadi norma hukum. Jika demikian maka keberlakuan norma kesusilaan itu menjadi norma hukum yang mengatur dan memberikan nilai-nilai dasar bersifat umum dan luas. Hanya saja tindakan ini memunculkan satu permasalahan baru, norma kesusilaan yang bagaimanakah dan manakah yang di anut di dalam norma hukum itu ketika mengingat banyaknya golongan masyarakat dalam bangsa Indonesia. Hal ini menimbulkan permasalahan dalam menginterpretasikan apakah suatu perbuatan itu melanggar norma kesusilaan atau tidak sebab bagi golongan masyarakat tertentu apresiasi terhadap norma kesusilaan itu sangat bervariasi. Bagi masyarakat Papua misalnya, apakah dapat dikatakan pakaian adat koteka mereka itu melanggar norma kesusilaan. Ataukah pakaian yang bernorma kesusilaan itu seperti pakaian adat jawa, kalimantan atau Sumatera saja. Terhadap hal ini norma kesusilaan harus diperjelas di dalam ketentuan hukum mengacu pada dasar dan nilai-nilai yang mana. Jangan sampai hanya mengacu pada norma kesusilaan yang dipahami secara parsial dan sektoral dari suatu golongan masyarakat.

Aspek penting dari pengaturan norma kesusilaan ini sendiri sebenarnya tidak terlepas dari pengakuan akan hak asasi manusia untuk berekspresi. Sebagai wujud kebutuhan bereksistensinya manusia baik sebagai individu atau masyarakat selalu mengekspresikan nilai-nilai kesusilaan nya itu dalam berbagai macam bentuk. Bisa dalam bentuk tarian, nyanyian, pakaian, kebiasaan, dll. Pengaturan akan norma kesusilaan dalam ketentuan hukum tentu saja tidak meliputi semua nilai-nilai norma kesusilaan yang ada di dalam suiatu masyarakat. Pengakuan norma kesusilaan ini sangat bergantung sampai seberapa jauh suatu ketentuan hukum itu memberikan pengaturan akan norma kesusilaan. Oleh karena itu sangat penting untuk memberikan penyebutan perbuatan apa dan bagaimana secara jelas yang melanggar norma kesusilaan. Dalam kaitannya dengan hukum pidana Remmelink menyatakan: 


\begin{abstract}
Hukum Pidana mempunyai sifat preventif manakala tidak terjadi perbuatan yang mengancam keberlakuan norma, dan bersifat represif ketika terjadi perbuatan pelanggaran terhadap norma yang diwujudkan dalam pemberian sanksi bagi pelanggarnya. ${ }^{19}$
\end{abstract}

Pengaturan norma kesusilaan ini sendiri tidak merupakan pelanggaran atas pengakuan hak asasi manusia yang merupakan hak konstitusional tetapi justru merupakan satu bentuk pengakuan dan pengaturan agar jangan sampai pelaksanaannya merugikan hak dari orang lain. Hal yang menarik sebagaimana di ungkapkan oleh Remmelinjk tentang hubungan norma dan sanksi di dalam hukum pidana itu dapat dijelaskan bahwa setiap penjatuhan sanksi pidana itu harus di dasarkan atas pemahaman dan terbuktinya pelanggaran dari suatu perbuatan terhadap norma hukum dan bukan pada norma yang lain. Konklusinya, Remmelink memandang bahwa pada setiap bagian hukum didalamnya terdapat norma yang diatur, bedanya dengan hukum pidana yang tidak menawarkan perlindungan menyeluruh atas kepentingan atau kebendaan hukum (rechtsgoederen) maupun pengaturan hubungan-hubungan hukum, melainkan hanya berkenaan dengan upaya melawan hukum sebagian kecil dari bentuk-bentuk pelanggaran hukum yang harus dianalisis lebih lanjut. ${ }^{20}$ Berangkat dari pandangan ini penulis berpendapat bahwa penentuan sanksi di dalam ketentuan hukum pidana itu harus di dasarkan atas norma hukum. Di dalam hal norma kesusilaan di jadikan dasar untuk menilai maka harus di perjelas dan dipertegas nilai-nilai mana saja yang termasuk di dalam norma hukum dari sekian banyak norma kesusilaan yang berlaku di masyarakat. Ini berarti tidak semua nilai kesusilaan itu menjadi norma hukum secara serta merta. Harus di lakukan suatu pengujian dan langkah penemuan hukum dengan mempertimbangkan nilai-nilai hukum dan keadilan yang ada pada tiap kasusnya.

Pengaturan norma kesusilaan sebagai bagian dari norma bersifat publik dapat dilihat dalam pengaturan norma kesusilaan dalam beberapa ketentuan hukum sektoral, seperti tampak berikut ini:

\footnotetext{
${ }^{19}$ Ibid, hal. 8 .

${ }^{20}$ Ibid, hal. 7.
} 


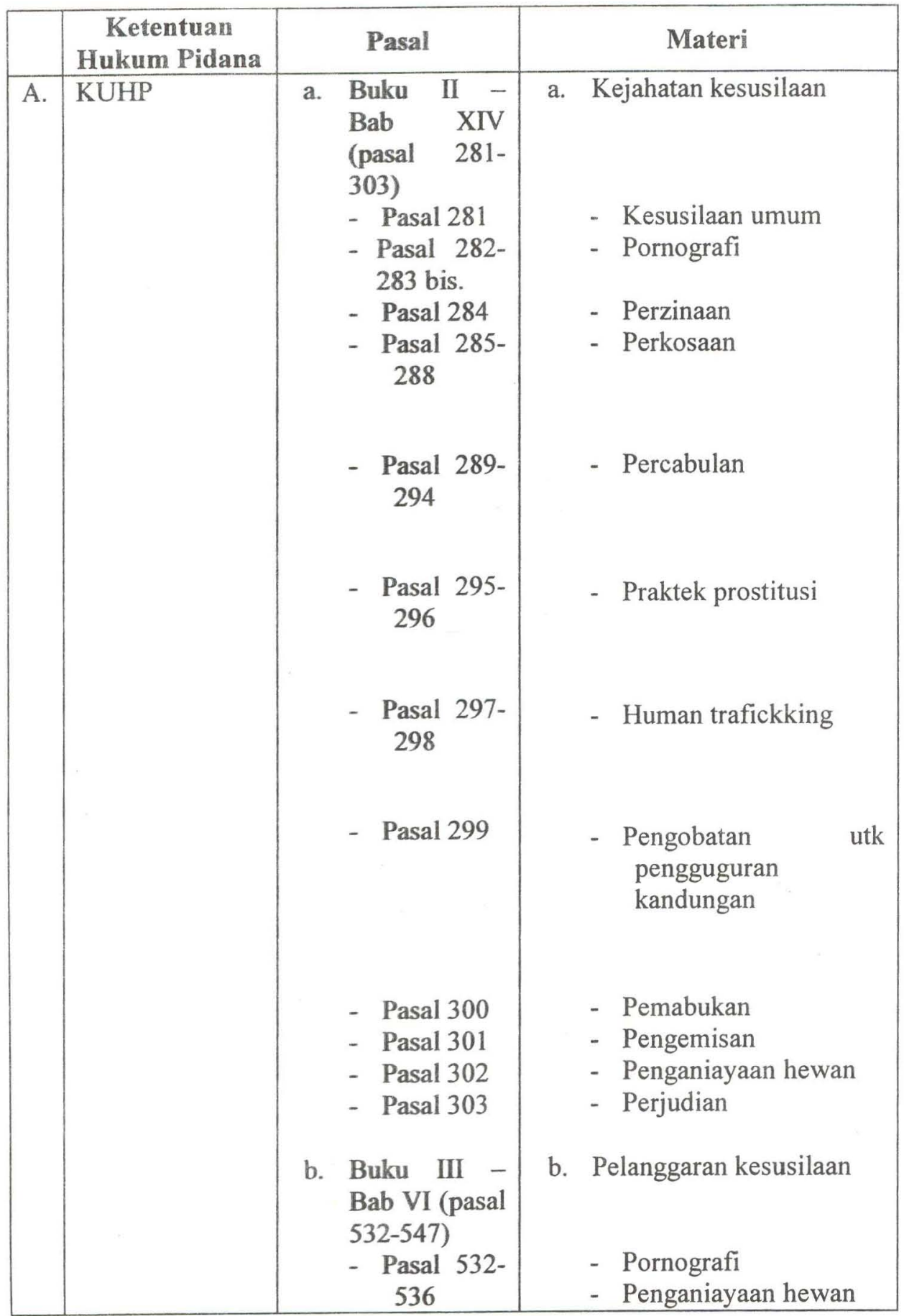




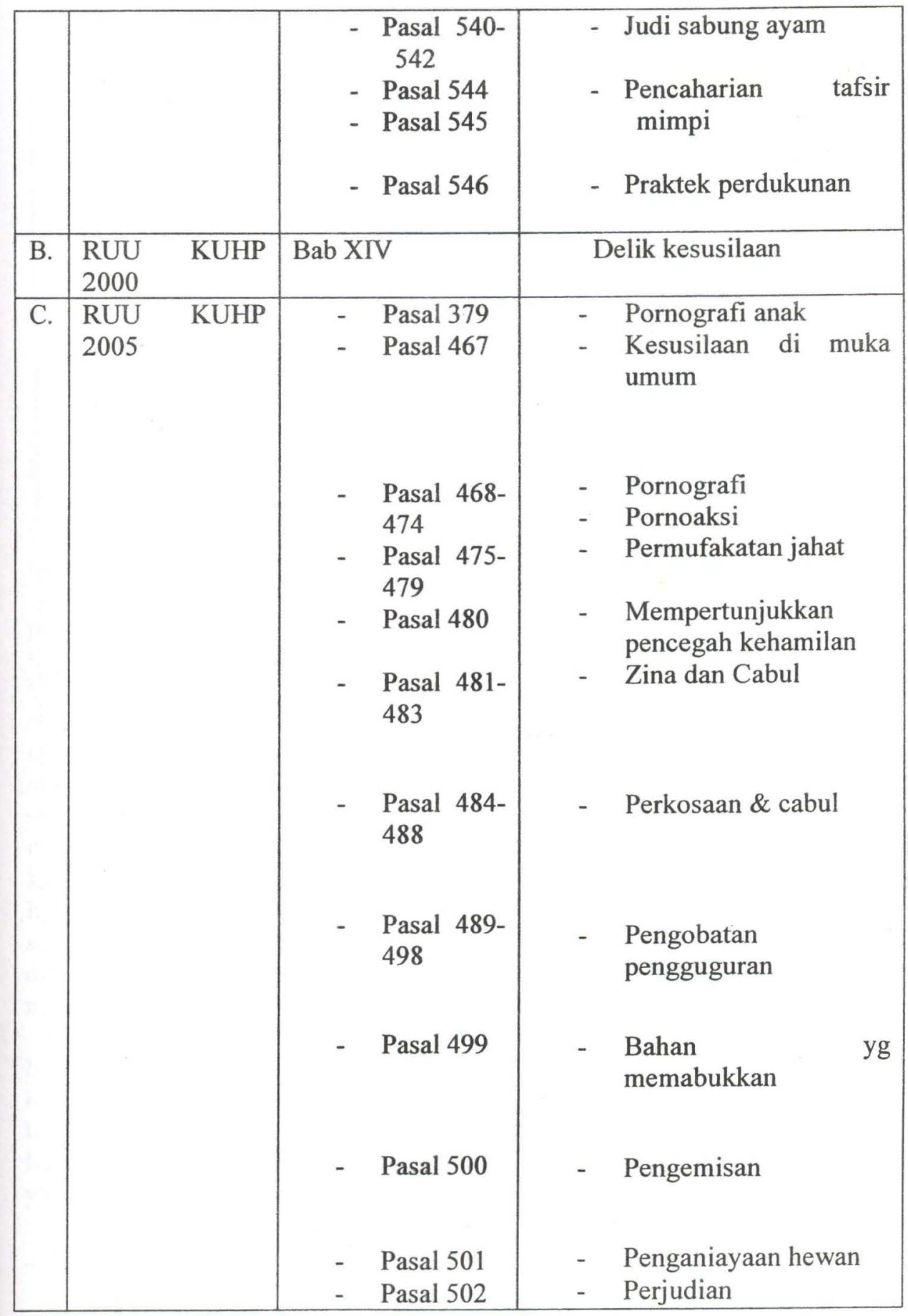




\begin{tabular}{|c|c|c|c|}
\hline & & $\begin{array}{l}\text { - Pasal 503- } \\
504\end{array}$ & \\
\hline B. & UU Pers & & \\
\hline C. & $\begin{array}{l}\text { UU } \\
\text { Telekomunikasi }\end{array}$ & $\begin{array}{l}\text { Pasal } 21 \text { jo. Pasal } \\
46\end{array}$ & $\begin{array}{lrr}\text { Pelarangan } & \text { dengan } & \text { sanksi } \\
\text { administrasi } & \text { bukan } & \text { sanksi } \\
\text { pidana. } & & \\
\end{array}$ \\
\hline D. & UU ITE & $\begin{array}{ll}- & \text { Pasal } 27 \\
& \text { ayat (1) jo. } \\
& \text { Pasal } 45 \\
& \text { ayat (1) } \\
- & \text { Pasal } 27 \\
& \text { ayat (2) jo. } \\
\text { Pasal } 45 \\
\text { ayat (1) }\end{array}$ & 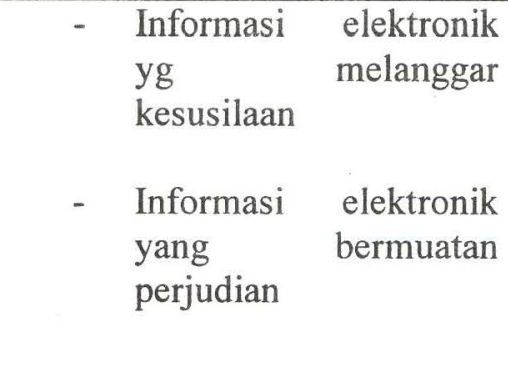 \\
\hline E. & UU HKI & $\begin{array}{ll}\text { a. } & \text { UU Merek } \\
\text { - } & \text { Pasal 5 } \\
& \text { huruf a } \\
\text { b. UU Paten } & \text { Pasal } 7 \\
\text { - } & \text { huruf a } \\
\text { c. UU Hak } \\
\text { Cipta } \\
\text { Pasal } 17 \\
\text { jo. Pasal } \\
72 \text { ayat (4) } \\
\end{array}$ & $\begin{array}{l}\text { a. Syarat substansi Merek } \\
\text { b. Proses/pelaksanaan } \\
\text { paten yg melanggar } \\
\text { kesusilaan } \\
\text { c. Pelarangan ciptaan } \\
\begin{array}{l}\text { yang } \\
\text { kesusilaan }\end{array}\end{array}$ \\
\hline F. & UU Penyiaran & $\begin{array}{ll}\text { - } & \begin{array}{l}\text { Pasal } 36 \\
\text { ayat (5) } \\
\text { huruf b jo. } \\
\text { Pasal } 57 \\
\text { huruf d }\end{array} \\
& \\
\text { - Pasal } 46 \\
\text { ayat (3) jo. } \\
\text { Pasal } 58 \\
\text { huruf d. }\end{array}$ & $\begin{array}{l}\text { - Isi siaran dilarang } \\
\text { menonjolkan } \\
\text { kekerasan, cabul, } \\
\text { perjudian dan obat } \\
\text { terlarang } \\
\text { - Isi siaran niaga } \\
\text { dilarang menampilkan } \\
\text { hal-hal asusila dan } \\
\text { eksploitasi anak di } \\
\text { bawah } 18 \text { th. }\end{array}$ \\
\hline
\end{tabular}




\section{Pornografi sebagai Perbuatan yang Melanggar Norma Kesusilaan}

Untuk dapat menentukan apakah suatu perbuatan itu melanggar suatu norma sangat bergantung pada seberapa jauh ruang lingkup pengertian dari norma kesusilaan itu sendiri. Jika norma kesusilaan itu dipandang sebagai suatu sistem nilai yang berisikan penilaian akan baik dan buruknya suatu perbuatan berdasarkan moral suatu individu maka pornografi sebagai perbuatan yang menempatkan seksualitas tidak sewajarnya jelas merupakan pelanggaran pada norma kesusilaan. Di dalam pornografi terkandung unsur pemberontakan terhadap tatanan seksualitas yang mapan seperti ketelanjangan merupakan hal yang bersifat rahasia bagi individu tetapi menjadi berubah manakala pornografi ini memahami berbeda dengan melakukan perbuatan telanjang di depan umum dengan pose atau gaya yang melecehkan atau tidak menghargai harkat dan martabat manusia. Pada kondisi inilah, perbuatan pronografi jelas telah melanggar norma kesusilaan sebagai bentuk perbuatan yang asusila. Jadi didapatkan satu pemahaman mendasar bahwa pornografi itu merupakan salah satu bentuk perbuatan yang pada hakekatnya melanggar nilai kepatutan dan moralitas dalam masyarakat.

Persoalan lebih lanjut, apakah bentuk sanksi yang dikenakan pada pelanggar norma kesusilaan ini sendiri jika ternyata belum terdapat ketentuan hukum secara tertulis yang mengatur. Dengan mengingat sumber norma kesusilaan itu dari hati nurani manusia secara pribadi ${ }^{21}$ maka pertimbangan dan ukuran nilai kesusilaan itu sebenarnya tidak bersifat subyektif tetapi universal. Jika manusia secara pribadi memhami dan mengakui satu bentuk nilai-nilai dasar atas moral, harkat dan martabat manusia (nilai susila) maka sebenarnya nilai ini pun juga dihayati secara sama oleh manusia secara umum. Dari dasar pemahaman ini diperoleh suatu pemahaman filosofis yang kuat terhadap pemberlakuan norma kesusilaan untuk menilai suatu perbuatan itu sebagai perbuatan yang asusila atau bukan termasuk pula menentukan sanksi nya. Pada tataran ini, pemberlakuan norma kesusilaan tidak hanya dilakukan oleh individu per individu ketika terjadi pelanggaran tetapi dari masyarakat terhadap individu yang melanggar.

Bentuk sanksi bagi pelanggar norma kesusilaan sebenarnya lebih bersifat komunal mengingat sumber norma kesusilaan itu sendiri berasal dari hati nurani per individu. Akan tetapi mengingat penghayatan dan standar dari tiap individu berbeda terhadap nilai susila ini maka di butuhkan peran lembaga masyarakat sebagai pengendali dan pemulih standar nilai susila yang berlaku. Bentuk sanksi yang di berikan sangat bergantung dari 
kesepakatan atau kebiasaan masyarakat itu sendiri, bisa berupa pengucilan, pengusiran dari kelompok masyarakat, bayar denda, dll.

\section{Perbandingan Konsep Hukum Pornografi menurut KUHP dan UU No. 44 Tahun 2008}

\section{Istilah dan Sejarah Pornografi}

Istilah "pornography" in sendiri sebenarnya berasal dari istilah Yunani yang berarti "writing about prostitutes".22 Sejarah pornografi sebenarnya berawal dari kebiasaan para pejabat Romawi yang pada saat itu menyenangi patung, lukisan atau gambaran yang berasosiasi seksual dengan tujuan meningkatkan gairah seksual. Kegiatan pornografi ini kemudian berkembang seiring dengan ditemukannya mesin cetak di awal abad ke 14, yang memungkinkan suatu produk yang berbau porno baik itu berupa gambar dan tulisan diproduksi dalam jumlah yang sangat banyak dan disebarluaskan. Oleh karena itu dapatlah dikatakan jika sebutan "porno" itu diberikan pada semua bentuk percabulan atau tindakan-tindakan jorok yang menonjolkan obyek seks. ${ }^{23}$ Tidak heran jika di dalam perkembangannya konsep pornografi sendiri mengalami pergeseran makna yang lebih luas, bukan hanya perbuatan yang menonjolkan obyek seks dengan menggunakan media tulis atau cetak tetapi mencakup pula kegiatan dalam bentuk lainnya. Kegiatan ini terwujud dalam beberapa bidang seperti pornografi, pornoaksi, pornomedia, dll.

Mengenai definisi pornografi sendiri, banyak ahli hukum yang berbeda pendapat seperti MacKinnon yang mengatakan:

...sexually explicit material which subordinates women through pictures or words. It would include scenes of women enjoying pain, humiliation and rape and penetration by objects or animals, or shown as bruised or hurt in acontext which makes these conditions sexual. ${ }^{24}$

${ }^{22}$ Susan M. Easton, "The Problem of Pornography: Regulation and the Right to Free Speech", (London: Routledge, 1994), hal. xi.

${ }^{23}$ M. Burhan Burgin, "Pornomedia: Sosiologi, Media, Konstruksi Sosial Teknologi Informatika dan Perayaan Seks di Media Massa", (Jakarta: Kencana, 2005), hal. 123.

${ }^{24}$ Catherine MacKinnon dalam Susan M. Easton, Op. Cit., hal. xii. 
Didalam Black's Law Dictionary istilah "pornography" di artikan sebagai "material (such as writings, pornographs, or movies) depicting sexual activity or erotic behavior in a way that is designed to arouse sexual excitement". ${ }^{25}$ di dalamnya Garner membedakan "pornography" dengan "pornographic", istilah "pornographic" lebih disamakan dengan istilah "obscenity" yang didefinisikan sebagai "the quality or state of being morally abhorrent or socially taboo, esp. as a result of referring to or depicting sexual or excretory functions". 26 di Amerika Serikat "obscenity" sendiri diakui sebagai sebuah istilah yuridis oleh Supreme Court dengan memberikan 3 (tiga) batu uji diantaranya a) the average persons, applying contemporary community standards, finds that a work as a whole appeals to prurient interests and b) the work depicts and describes in a "patently offensive way" sexual conduct, and c) it lacks serious literary, artistic, political or scientific value, it is obscene. ${ }^{27}$ Dari beberapa definisi di atas pemahaman akan pornografi lebih mengacu pada apa yang dijelaskan Blak's Law Dictionary yang menekankan 3 faktor utama yaitu 1) Materi: material (such as writings, pornographs, or movies), 2) sifat materi: depicting sexual activity or erotic behaviour dan 3) Kualifikasi sebagai tujuan pembuatan materi, designed to arouse sexual excitement. Ketiga faktor di atas cukup mewakili apa yang dimaksud dengan pornografi mengingat perbuatan pornografi sendiri meliputi ketiga hal itu secara kumulatif. Hanya saja memang dari definisi ini tercakup ruang lingkup yang begitu luas karena perbuatan ini bisa termasuk obscenity, adultery, dll.

\section{Kebijakan pengaturan Pornografi di dalam Ketentuan Hukum Pidana Nasional}

Kebijakan kriminalisasi perbuatan pornografi melalui hukum pidana nasional pertama kali dilakukan pada tahun 1808 dengan diberlakukannya Wetboek van Strafrecht voor Netherlands Indie (WvS NI yang saat ini dikenal

${ }^{25}$ Bryan A. Garner, "Black's Law Dictionary", Deluxe Seventh Edition, (US: West Group, 2001), hal. 1181.

${ }^{26}$ Ibid, hal. 1104.

27 Simon Whatney, "Policing Desire: Pornography, AIDS and the Media", (Minneapolis: University of Minnesota Press, 1987), hal. 61. 
dengan Kitab Undang-undang Hukum Pidana) berdasarkan asas konkordansi. Pemberlakuan asas ini ditegaskan di dalam UU No. 1 Tahun 1946 yang ditujukan untuk mengisi kekosongan hukum nasional yang ada mengingat pada saat itu Indonesia masih Negara baru. Dari kebijakan pemberlakuan WvS NI ini sebenarnya dapat diketahui dengan jelas bahwa bangsa Indonesia pada dasarnya sama dengan bangsa lain mengecam dan melarang perbuatanperbuatan sebagaimana tercantum di dalam Buku II dan Buku III sebagai perbuatan yang terlarang. Garis kebijakan nasional bangsa Indonesia sendiri tercermin di dalam Pancasila yang menjunjung tinggi nilai kemanusiaan yang beradab (sila II Pancasila "Kemanusiaan yang adil dan beradab"). Menyadari arti penting menujunjung tinggi nilai kemanusiaan yang beradab ini bangsa Indonesia sebagai Negara yang berdaulat pada saat itu dengan tegas menentukan perbuatan apa saja yang terlarang di dalam ketentuan hukum pidananya. Hal ini begitu penting dilakukan oleh sebuah Negara atau bangsa mengingat melalui hukum pidana-lah dapat dilihat dengan jelas apakah suatu bangsa itu beradab ataukah tidak. ${ }^{28}$

Pelarangan perbuatan pornografi didalam KUHP sendiri tidak secara jelas dan tegas di cantumkan dalam ketentuan hukumnya. Baik di dalam Buku II dan Buku III, KUHP hanya mengenal "delik susila" yang diatur di dalam pasal 281-303 KUHP sebagai bentuk Kejahatan (misdrijven) dan Pasal 531-547 KUHP sebagai pelanggaran (overtredingen). Jika dilihat dari bentuk rumusan delik susila di dalam KUHP, dapat diperoleh suatu ruang lingkup yang sangat luas dan tidak jelas tentang sampai dimana ukuran perbuatan itu "melanggar kesusilaan". Ketidakjelasan inilah yang pada praktek menimbulkan perbedaan pemahaman atau penafsiran sampai sejauh mana suatu tindakan itu dapat dikatakan melanggar kesusilaan. Untuk meluruskan kesimpangsiuran ini, hakim dengan mempertimbangkan setiap kasusnya membuat satu putusan tentang sampai seberapa jauh suatu perbuatan itu melanggar kesusilaan.

Perkembangan pengaturan pornografi ini pun mulai di rasakan perlu mengingat semakin berkembangnya masyarakat dalam menerima semua perkembangan teknologi yang ada.

${ }^{28}$ Andi Hamzah, "Hukum Pidana merupakan Salah satu Cermin Paling Terpercaya mengenai Peradaban suatu Bangsa", dalam I Made Widnyana (ed.), et. all, dalam "Bunga Rampai Pembangunan Hukum Indonesia", (Bandung: Eresco, 1995), hal. 35-37. 


\section{A. Konsep Hukum Pornografi menurut Kitab Undang-undang Hukum Pidana}

Sejak diberlakukannya Wetboek van Strafrecht voor Netherlands Indie yang dikenal dengan nama Kitab Undang-undang Hukum Pidana secara nasional Indonesia dapat dikatakan telah memiliki Hukum Pidana Positif. Terkait dengan masalah "pornografi" ternyata KUHP tidak mengenal dan mengatur secara tegas satu jenis perbuatan pidana itu. Hanya saja di dalam rumusannya lebih dimasukkan dalam "delik kesusilaan". Pengaturan delik susila ini terdapat di dalam pasal 281, 282 dan 283 KUHP yang merupakan kelompok Kejahatan dan pasal 532, pasal 533, pasal 534 dan pasal 535 KUHP dalam kelompok perbuatan pelanggaran kesusilaan.

Dari masing-masing perumusan ketentuan hukum di atas sebenarnya terdapat satu syarat yang sama untuk dapat menilai suatu perbuatan itu sebagai delik susila, yaitu "melanggar kesusilaan" (aanstotelijk voor de eerbarheid). Tentang apa yang dimaksud dengan "melanggar kesusilaan", KUHP sendiri tidak memberikan penjelasan yang memadai. Hanya saja untuk memahami pengertian "melanggar kesusilaan" ini dapat di perhatikan setiap perkembangan putusan pengadilan yang merupakan yurisprudensi beserta pendapat ahli hukum. Hal ini sesuai dengan pendapat Sutiyoso yang mengusulkan agar pemahaman terhadap perngetian "melanggar kesusilaan" ini harus diserahkan kepada ilmu pengetahuan dan yurisprudensi untuk menegaskannya sesuai dengan keadaan setempat dan perkembangan zaman. $^{29}$

Hoge Raad di dalam Putusannya tanggal 21 April 1908, W. 8706 dan 15 Januari 1934, N.J. 1934, 919, W. 12736 menegaskan maksud "melanggar kesusilaan" itu dengan "suatu tulisan atau gambar itu disebut menyinggung kesusilaan, apabila tulisan atau gambar itu mempunyai tujuan semata-mata untuk menimbulkan atau merangsang nafsu". ${ }^{30}$ Lebih lanjut di dalam putusannya tanggal 12 April 1920, N.J. 1920, 446, W. 10551, Hoge Raad menyimpulkan "untuk dapat dikatakan menyinggung kesusilaan, sesuatu tulisan itu haruslah seluruh isinya menyinggung kesusilaan dan adalah tidak cukup jika

${ }^{29}$ Bambang Sutiyoso, “Aktualita Hukum dalam Era Reformasi”, (Jakarta: Rajawali Pers, 2004), hal. 84.

173.

${ }^{30}$ P.A.F. Lamintang, "Hukum Pidana Indonesia", (Bandung: Sinar Baru, 1990), hal. 
yang meyinggung kesusilaan itu adalah hanya babnya saja ataupun hanya satu halaman saja". "Oleh karena itu dari dua pendapat Hoge Raad ini dapat disimpulkan maksud "melanggar kesusilaan" sebagai perbuatan yang dengan tujuan utama merangsang nafsu. Mengapa hal ini menjadi satu dasar pertimbangan penting di dalam putusan Hoge Raad, van Bemmelen menjelaskan hal ini dengan menekankan maksud pemidanaan delik kesusilaan ini untuk melindungi anak-anak muda, supaya mereka jangan sampai mengalami gangguan dalam perkembangan seksual mereka dan melindungi orang yang tidak berdaya (misalnya dalam keadaan pingsan) terhadap perkosaan seksual. $^{32}$ Dilihat dari latar belakang pembentukannya, perkataan "melanggar kesusilaan" di muka umum (dalam istilah berbeda van Bemmelen memakai "kehormatan kesusilaan") berasal dari outrage public á la pudeur pasal 330 Code Penal sehingga dapat diterjemahkan dengan "tidak ada kesopanan di bidang seksual". Di dalam menentukan standar dari 'sopan' ini, van Bemmelen kembali menjelaskan hakekat 'sopan' ini sebagai suatu pengertian obyektif untuk apa yang dianggap sebagai sopan sesuai dengan "perasaan malu yang normal",33 sehingga di peroleh suatu pemahaman dan dasar yang obyektif tentang apa itu yang melanggar kesusilaan sama dengan apa yang melanggar kesopanan dalam keadaan yang normal. Terhadap pemahaman "melanggar kesusilaan" ini Langemeijer sebagaimana dikutip oleh van Bemmelen mencoba merumuskan 5 (lima) kriteria yang harus dipenuhi:

1) pertunjukkan yang jika diperlihatkan kepada orang lain dirasakan oleh orang lain itu sebagai pelanggaran terhadap perasaan halusnya, berbeda dengan jika diperlihatkan dalam lingkungan akrab sendiri;

2) cara bagaimana pertunjukkan itu diperlihatkan, apabila itu dinyatakan dengan suasana hati yang kasar dan kurang ada perhatian mengenai pokok persoalan yang biasanya dirasakan sebagai menyinggung perasaan;

3) alasan-alasan yang menimbulkan dugaan pada pernyataan, apabila atau alasan-alasan itu sendiri kurang baik atau

${ }^{31}$ Ibid, hal. 174.

32 J.M. van Bemmelen, "Hukum Pidana 3: Bagian-bagian khusus Delik-delik Khusus", (Bandung: Binacipta, 1986), hal. 173.

${ }^{33}$ Ibid., hal. 178. 
setidak-tidaknya tidak mempunyai nilai yang produktif yang dapat membenarkan pernyataan yang mengagetkan.

4) Cara bagaimana pernyataan itu dipaksakan kepada orang lain;

5) akibat-akibat tidak langsung, misalnya akibat terhadap anakanak yang belum dewasa.

Dari kelima syarat ini, sebenarnya Langemeijer tidak sedang menjelaskan perkataan "melanggar kesusilaan" namun lebih berfokus pada bentuk formal dari melanggar kesusilaan itu sendiri.

Mengenai "pornografi" sendiri, van Bemmelen melihatnya sebagai bentuk perbuatan yang melanggar kesusilaan melalui bukubuku, tulisan, gambar atau benda seperti tercakup dalam rumusan pasal 240, 240 bis dan 240 ter $\mathrm{Sr}^{34}$ (pasal 281, 282 dan 283 KUHP). Ini berarti perbuatan pornografi berada di dalam ruang lingkup delik kesusilaan dan merupakan salah satu bentuk delik kesusilaan secara umum.

Perkembangan pemahaman tentang batasan nilai kesusilaan ini pada saat ini telah berkembang ke arah yang lebih luas. Norma kesusilaan tidak lagi dipahami sebatas perbuatan yang terkait dengan masalah seksual tetapi juga masalah yang melanggar nilai moral dan harkat martabat manusia. Roeslan Saleh mengusulkan agar "pengertian kesusilaan hendaknya tidak dibatasi pada pengertian kesusilaan dalam bidang seksual tetapi juga meliputi hal-hal lain termasuk dalam penguasaan norma-norma kepatutan bertingkah laku dalam masyarakat". ${ }^{35}$ Jika pemahaman norma kesusilaan di dasarkan atas pandangan ini, berarti pemahaman akan kesusilaan itu sendiri akan sangat meluas dan bisa meliputi semua perbuatan baik yang melanggar norma agama, norma kesopanan atau adat maupun norma hukum. Dalam pemahaman yang hampir senada Barda Nawawi Arief juga mengusulkan "penentuan delik kesusilaan itu harus berdasarkan pada 'nilai-nilai kesusilaan nasional' yang sudah disepakati bersama dan memperhatikan nilai-nilai kesusilaan yang hidup dalam masyarakat". ${ }^{36}$ Untuk menentukan nilai kesusilaan ini Barda

\footnotetext{
${ }^{34}$ Ibid., hal. 184.
}

${ }^{35}$ Roeslan Saleh, "Bab-bab Kodifikasi Hukum Pidana", (buku II), dalam Lokakarya BPHN, Jakarta 23-25 April 1985.

${ }^{36}$ Barda Nawawi Arief, "Bunga Rampai Kebijakan Hukum Pidana", (Bandung: Citra Adutya Bakti, 2002), hal. 267. 
mengusulkan adanya Nilai-nilai kesusilaan nasional yang di sepakati ditambah nilai-nilai kesusilaan yang hidup dalam masyarakat. Dari pendapat ini, tersimpulkan cita-cita pembentukan hukum nasional yang baik yaitu adanya kodifikasi hukum pidana nasional dengan menetapkan suatu nilai-nilai kesusilaan nasional.

Tetapi usaha ini ternyata di sadari tidak mudah karena keberadaan nilai kesusilaan sebagai sebuah norma di dalam masyarakat itu terus berkembang secara progresif dan di maknai dalam ekspresi yang berbeda dalam penerapannya. Pendapat Barda ini di satu sisi mencitacitakan nilai kesusilaan yang baku tetapi disisi lain juga ingin agar kebakuan nilai susila ini dapat terus mengikuti perkembangan nilai kesusilaan yang ada di dalam masyarakat. Pemahaman seperti ini merupakan pendekatan terhadap penilain norma kesusilaan yang bersifat antisipatif karena menyadari adanya perbedaan dalam tiap kasus kesusilaan yang terjadi.

\section{B. Konsep Hukum Pornografi menurut Undang-undang Nomor 44 Tahun 2008 tentang Pornografi}

Pasal 1 angka 1 UU No. 44 Tahun 2008 menegaskan definisi pornografi sebagai:

Pornografi adalah gambar, sketsa, ilustrasi, foto, tulisan, suara, bunyi, gambar bergerak, animasi, kartun, percakapan, gerak tubuh, atau bentuk pesan lainnya melalui berbagai bentuk media komunikasi dan latau pertunjukan di muka umum, yang memuat kecabulan atau eksploitasi seksual yang melanggar norma kesusilaan dalam masyarakat. (garis bawah dari penulis)

Unsur rumusan "pornografi" terdiri dari:

a. Obyek, berupa gambar, sketsa, ilustrasi, foto, tulisan, suara, bunyi, gambar bergerak, animasi, kartun, percakapan, gerak tubuh, atau bentuk pesan lainnya;

b. Syarat kualifikasi obyek: memuat kecabulan/eksploitasi seksual yang melanggar norma kesusilaan dalam masyarakat;

c. Publisitas: melalui berbagai bentuk media komunikasi dan/ atau pertunjukan di muka umum.

Jika rumusan di atas di bandingkan dengan rumusan definisi pornografi menerut Black's Law akan tampak bahwa UU No. 44 Tahun 2008 lebih memberikan batasan yang sifatnya memperkecil ruang lingkup pornografi. Seperti diketahui Black's Law memahami 
Pornografi sebagai semua materi yang bermuatan seksual dengan tujuan untuk meningkatkan atau menimbulkan nafsu seksual bagi penikmatnya sedangkan pasal 1 angka 1 UU No. 44 Tahun 2008 lebih memberikan pengaturan semua materi yang berisikan eksploitasi seksual dan di publikasikan. Perbedaan ini cukup signifikan untuk ditelaah lebih lanjut karena menyangkut kebijakan perumusan suatu perbuatan pidana pornografi di dalam UU No. 44 Tahun 2008 sangat spesifik. Untuk memahami perbedaan ini di sajikan bagan perbandingan sekaligus hubungan antara konsep pornografi menurut Black's Law dengan UU No. 44 Tahun 2008.

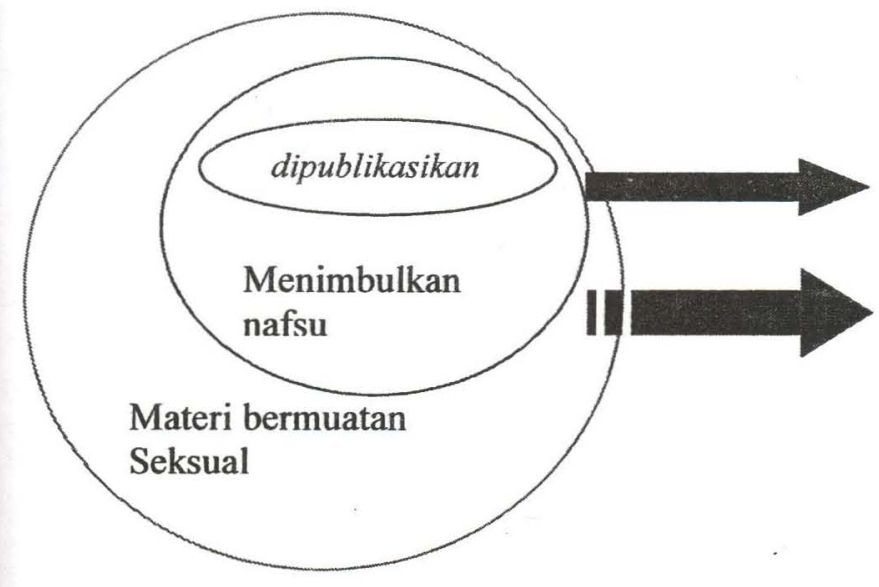

Definisi UU No. 44 Tahun 2008

Definisi

Black's Law

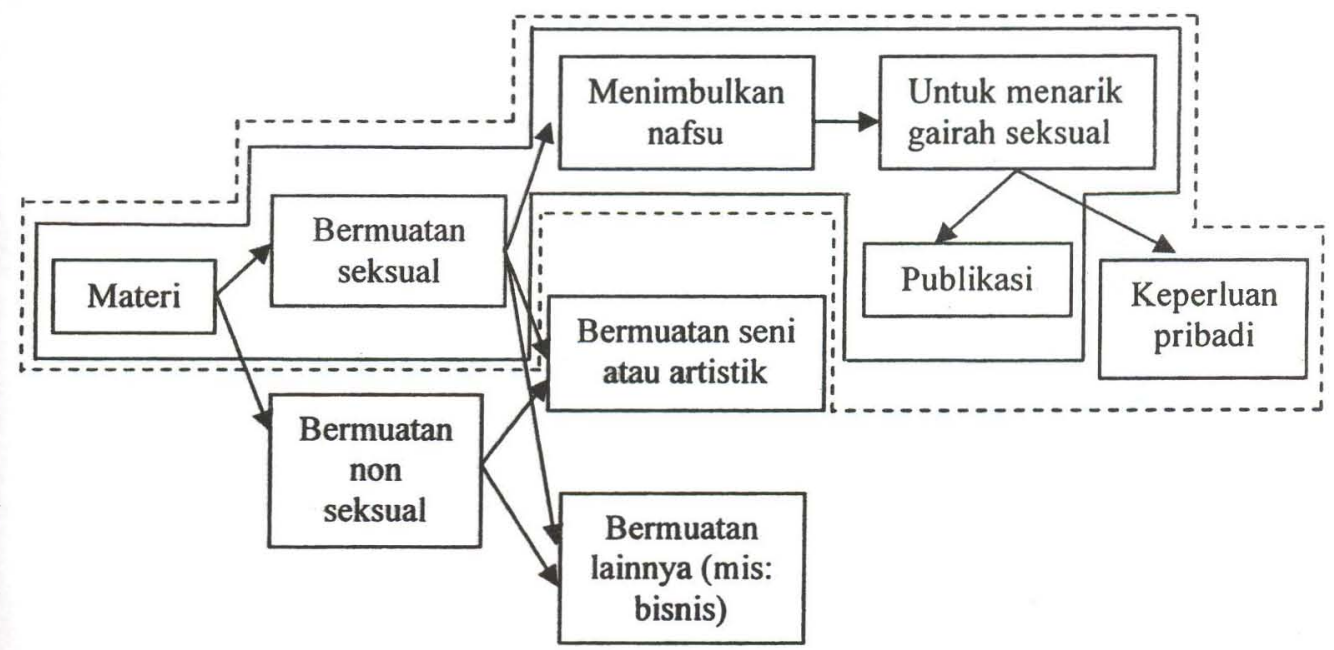


Dari kedua bagan di atas dapat di lihat suatu perbedaan yang tajam terhadap model perumusan perbuatan pornografi. Pada Black's Law lebih mendefinisikan pornografi secara materiil sedangkan UU No. 44 Tahun 2008 lebih merumuskannya secara formiil. Sebagai akibatnya, ruang lingkup dan pembuktian ada atau tidaknya perbuatan pidana pornografi dalam UU No. 44 Tahun 2008 lebih susah karena harus memenuhi tiga unsur utama yang diatur. Dari ketiga unsur utama pembentuk rumusan pornografi itu sebenarnya pasal 1 angka $1 \mathrm{UU}$ No. 44 Tahun 2008 menegaskan 2 (dua) unsur utama sebagai penentu ada atau tidaknya perbuatan pornografi. Kedua unsur itu adalah unsur kualifikasi dan unsur publisitas.

Sebuah materi atau obyek atau tindakan itu harus bermuatan seksual ke arah eksploitasi seksual dan di publikasikan di muka umum. UU No. 44 Tahun 2008 secara eksplisit mencantumkan 'batu uji' bagi obyek yang bermuatan seksual dan berisi eksploitasi seksual ini melalui norma kesusilaan. Hanya saja penyebutan norma kesusilaan sebagai ‘batu uji' di dalam UU No. 44 Tahun 2008 ini tidak di jelaskan lebih lanjut. Baik dalam penjelasan umum atau penjelasan pasal 1 angka 1 tidak ditemukan deskripsi maksud dari norma kesusilaan itu sendiri. Keadaan ini memunculkan pertanyaan bagi kepastian hukum tentang batasan dari suatu perbuatan itu dapat dikatakan pornografi karena ketidakjelasan sangat merugikan hak masyarakat dan melanggar asas legalitas. Jika dilihat dalam penjelasan umum, maksud pengaturan UU No. 44 Tahun 2008 ini salah satunya adalah untuk "memberikan ketentuan yang sejelas-jelasnya tentang batasan dan larangan yang harus dipatuhi oleh setiap warga negara serta menentukan jenis sanksi bagi yang melanggarnya; ...". Hal yang menarik di dalam penjelasan umum UU No. 44 Tahun 2008 juga di sebutkan landasan pertimbangan pembentukan UU No. 44 Tahun 2008 ini meliputi Ketuhanan Yang Maha Esa, penghormatan terhadap harkat dan martabat kemanusiaan, kebhinekaan, kepastian hukum, non diskriminasi, dan perlindungan warga negara. Ini berarti norma kesusilaan ini dalam penerapannya masih harus di tinjau lagi menurut 6 faktor atau asas hukum di atas. Di sinilah tugas dan peranan hakim untuk menggali dan mendapatkan dengan tepat ada atau tidaknya norma kesusilaan yang di langgar dalam satu perkara dengan tetap mendasarkan dirinya pada keenam asas di atas. Ada baiknya pemahaman terhadap norma kesusilaan ini dilakukan secara proposional dengan tetap memperhatikan tiap asas dan nilai yang berlaku di suatu masyarakat. Dengan demikian pemahaman terhadap konsep pornografi masih bersifat kasuistis tergantung dari seberapa 
jauh norma kesusilaan itu berinteraksi dengan asas atau norma yang ada di masyarakat secara luas dan pada perkara itu pada khususnya. Di dalam pengujian perkara kesusilaan ini asas dan nilai dasar di dalam Pancasila ${ }^{37}$ harus benar-benar menjadi pedoman dan dasar yang teguh sehingga tercipta suatu pembangunan hukum pidana kesusilaan yang berlaku secara nasional. Pada satu nilai dasar di dalam Pancasila inilah kita bersama-sama mengakui satu hakekat harkat dan martabat manusia yang sama dan menjadi kepribadian bangsa Indonesia.

\section{Penutup}

Penggunaan norma kesusilaan sebagai dasar untuk menentukan ada atau tidaknya perbuatan pornografi di dalam UU No. 44 Tahun 2008 memang berpotensi menimbulkan multi interpretasi terhadap eksistensi suatu perbuatan pornografi. Hal ini didasarkan bahwa tidak semua nilai-nilai kesusilaan yang berlaku di dalam masyarakat dapat diberlakukan secara serta merta tanpa pertimbangan akan aspek keadilan dan keunikan budaya. Menghadapi tantangan ini, adalah tugas dari para penegak hukum untuk berhati-hati dalam menilai dan mengkaji secara lebih teliti apakah suatu obyek atau perbuatan itu bermuatan pornografi ataukah tidak. Batasan ini dapat diambil dengan memegang pemahaman terhadap norma kesusilaan secara materiil, mempertimbangkan aspek budaya sekaligus keadilan pada tiap kasusnya. Karena mengingat tidak semua golongan atau kelompok masyarakat itu menghayati norma kesusilaan secara sama. Namun tidak berarti kelompok masyarakat itu tidak mengakui berlakunya norma kesusilaan.

Sedangkan terhadap cita-cita pembentukan norma kesusilaan yang berlaku secara nasional, kebijakan politik hukum ini harus tetap mendasarkan dirinya pada semangat Pancasila dan UUD 1945 yang ingin melindungi budaya bangsa sebagai bentuk kepribadian bangsa secara selektif dengan menghindari pemusnahan nilai-nilai adat yang berlaku.

${ }^{37}$ S.R. Nur, "Membina Hukum Adat menjadi Penghayatan Pancasila di bidang Hukum", dalam I Made Widnyana, "Bunga Rampai Pembangunan Hukum Indonesia", (Bandung: Eresco, 1995), hal. 189-190. 


\section{Daftar Pustaka}

\section{Buku}

Arief, Barda Nawawi. Bunga Rampai Kebijakan Hukum Pidana, Bandung: Citra Adutya Bakti. 2002.

Bemmelen, J.M. van. Hukum Pidana 3: Bagian-bagian khusus Delik-delik Khusus, Bandung: Binacipta. 1986.

BPHN. Simposium Pengaruh Kebudayaan/agama terhadap Hukum Pidana, Bandung: Bina Cipta. 1975.

Bruggink, J.J.H. Refleksi tentang Hukum, (alih bahasa: Arief Sidharta). Bandung: Citra Aditya Bakti. 1999.

Burgin, M. Burhan. Pornomedia: Sosiologi, Media, Konstruksi Sosial Teknologi Informatika dan Perayaan Seks di Media Massa, Jakarta: Kencana. 2005.

Chazawi, Adami. Tindak Pidana mengenai Kesopanan, Jakarta: Rajawali Pers. 2005.

Easton, Susan M. The Problem of Pornography: Regulation and the Right to Free Speech, London: Routledge. 1994.

Garner, Bryan A. Black's Law Dictionary, Deluxe Seventh Edition. US: West Group. 2001.

Lamintang, P.A.F. Hukum Pidana Indonesia, Bandung: Sinar Baru. 1990.

Marzuki, Peter Mahmud. Pengantar Ilmu Hukum, Jakarta: Kencana Prenda Media. 2008.

Mertokusumo, Sudikno. Mengenal Hukum, Yogyakarta: Liberty. 1999.

Pound, Roscoe. Law Finding through Experience and Reason: Three Lestures, Athens: University of Georgia Press. 1960.

Prodjodikoro, Wirjono. Tindak-tindak Pidana tertentu di Indonesia, Bandung: Eresco. 1991.

Saleh, Roeslan, Bab-bab Kodifikasi Hukum Pidana, dalam, Buku II Lokakarya BPHN, 23-25 April 1985, Jakarta.

Soedarto. Hukum dan Hukum Pidana, Bandung: Alumni. 1986.

Sutiyoso, Bambang. Aktualita Hukum dalam Era Reformasi, Jakarta: Rajawali Pres. 2004. 
Remmelink, Jan. Hukum Pidana: Komentar atas Pasal-pasal Terpenting dari Kitab Undang-undang Hukum Pidana Belanda dan Padanannya dalam Kitab Undang-undang Hukum Pidana Indonesia, Jakarta: Gramedia Pustaka Utama. 2003.

Whatney, Simon. Policing Desire: Pornography, AIDS and the Media, Minneapolis: University of Minnesota Press. 1987.

Widnyana, I Made. Bunga Rampai Pembangunan Hukum Indonesia, Bandung: Eresco. 1995.

Widodo, Ismu Gunadi. Aspek Yuridis Pornorafi/Aksi: Memahami Wewenang Diskresi dalam Penyidikan Tindak Pidana Pornografi/ Aksi, Surabaya: Airlangga University Press. 2006.

\section{Jurnal Hukum}

Atmadja, "Asas Patut sebagai Asas Kerja Penyelesaian Perkara menurut Hukum Adat Bali", Majalah Hukum \& Pembangunan, Tahun XI, No. 1 Januari 1981.

Topo Santoso, "Masalah Delik Perzinahan di Indonesia Dewasa Ini", Majalah Hukum \& Pembangunan, Tahun XXV, No.2, April 1995. 